\title{
Productivity and Economic Assessment of Maize and Soybean Intercropping under Various Tillage and Residue Levels in Chitwan, Nepal
}

\author{
N. Khatri ${ }^{1, *}$, K.R. Dahal ${ }^{1}$, L.P. Amgain ${ }^{2}$, T.B. Karki ${ }^{2}$ \\ ${ }^{1}$ Institute of Agriculture and Animal Science, Rampur, Chitwan, Nepal \\ ${ }^{2}$ Nepal Agricultural Research Council, National Maize Research Program, Rampur, Chitwan, Nepal \\ *Corresponding author: narayan.iaas068@gmail.com
}

Received October 11, 2014; Revised November 12, 2014; Accepted December 28, 2014

\begin{abstract}
A field experiment was conducted at National Maize Research Program (NMRP) in Rampur, Chitwan, Nepal during May-Nov 2013. The experiment was laid out in strip- split design with twelve treatments and three replications. Treatments consisted of two different tillage methods namely conventional tillage (CT) and zero tillage (ZT) as vertical factor, two different levels of residue (residue kept and residue removed) as horizontal factor and three different levels of cropping systems namely sole maize, sole soybean and maize + soybean intercropping system as sub plot factor. Manakamana-3 and Puja were the variety of maize and soybean used for the experiment respectively. The results revealed that the grain yield and yield attributing components of maize and soybean was significantly influenced by cropping systems but not by tillage methods and residue levels. The grain yield of maize obtained under sole cropping $\left(4.76 \mathrm{tha}^{-1}\right)$ was significantly higher than maize + soybean intercropping system (4.27 $\left.t h^{-1}\right)$. Similarly, the grain yield of sole soybean was significantly higher $\left(1.99 \mathrm{tha}^{-1}\right)$ than that of maize + soybean intercropping system $\left(1.26 \mathrm{t} \mathrm{ha}^{-1}\right)$. Moreover, the total grain yield equivalent of $6.45 \mathrm{t} \mathrm{ha}^{-1}$ obtained from sole soybean system was significantly higher and was followed by maize and soybean intercropping system with $4.99 \mathrm{t}$ $\mathrm{ha}^{-1}$. Whereas, sole maize produced significantly the lowest maize grain yield equivalent of $3.47 \mathrm{t} \mathrm{ha}^{-1}$. Significantly, higher LER (1.38) was recorded with maize and soybean intercropping system over sole system (1.0). Tillage and residue levels did not affect the gross and net return and B: C ratio but the effect was found obvious due to intercropping system. Significantly higher net return (NRs.140.49 thousands ha $^{-1}$ ) was recorded in intercropping of maize with soybean as compared to sole soybean (NRs. 89.85 thousands ha ${ }^{-1}$ ) which was at par with sole maize system (NRs. 80.91 thousands ha ${ }^{-1}$ ). Maize and soybean intercropping system produced significantly the higher (2.47) B: C ratio than sole soybean (2.28) and was at par with sole maize (2.18).
\end{abstract}

Keywords: maize, soybean, tillage, residue, intercropping, yield

Cite This Article: N. Khatri, K.R. Dahal, L.P. Amgain, and T.B. Karki, "Productivity and Economic Assessment of Maize and Soybean Intercropping under Various Tillage and Residue Levels in Chitwan, Nepal." World Journal of Agricultural Research, vol. 2, no. 6A (2014): 6-12. doi: 10.12691/wjar-2-6A-2.

\section{Introduction}

Maize (Zea mays L.) is one of the main food crop and the main source of livelihood and income of the major segment of population in Nepal. The crop contributes about $6.54 \%$ in gross agricultural domestic product (AGDP) and $3.15 \%$ to gross domestic production (GDP) (MoAD, 2013). Maize is the important staple food crop of hills and is placed second after rice in Nepal in terms of both area and production. It occupies about $27.49 \%$ of total cultivated area and shares about $25.02 \%$ of the total cereal production (MoAD, 2012) playing an important role in national food security.

Maize is usually intercropped with soybean, finger millet and beans depending on rainfall and farmers requirements because of longer duration of maize, it is difficult to grow sequential crops after it during the short rainy season. Maize and soybean intercropping is predominant in western and southwestern hills in relatively dry seasons, to avoid the risk of crop failure. Soybean is considered as an ideal crop for intercropping with maize owing to its comparative tolerance for shade and drought, efficient light utilization and utilizes soil moisture efficiently (Wright et al., 1988).

Maize based cropping system using high intensive tillage is predominant in the sloping hill terraces. These sloping terraces suffer more soil runoff loss. Since, the problem of soil loss is partly natural and partly human induced, need of appropriate technological intervention based on land use suitability, have drawn attention of the researchers. Resource conservation technologies, for example, minimum tillage have shown better performance in most part of the world in restoring the organic matter and increasing crop yield in long run (Cassel et al.,1995). Decreasing soil fertility, increased soil erosion, poor water 
infiltration and increased soil compaction are the other major constraints of maize production system brought about by the conventional agricultural practice which is more labor intensive mainly for repeated land preparations and intercultural operations. Conservation agriculture may be a viable alternative to make maize farming sustainable while conserving the soil.

Recently, zero tillage with residue retention has been studied in maize under maize based cropping system of Nepal. The crop residues left on the surface have advantages of reducing surface run-off and subsequent soil losses. This means less nutrients are lost and more water is available for crop growth.. Legumes are the principal components of maize based system and are valuable in terms of food security and soil fertility restoration. However, legumes intercropping with maize as a component technology of conservation agriculture have not been tested so far to date in Nepal and there is an urgent need to generate pertinent information on this aspect of maize farming through research. Hence, this experiment was carried out in order to evaluate the agronomic and economic performance of maize and soybean intercropping under various tillage and residue levels.

\section{Materials and Methods}

A field experiment was conducted at National Maize Research Program (NMRP) farm, Rampur, Chitwan during summer season from May 2013 to November 2013. This location is situated in central Nepal with subtropical climate and is $10 \mathrm{~km}$ west from Bharatpur, headquarter of Chitwan district. Geographically it is located at $27^{\circ} 37^{\prime}$ north latitude and $84^{\circ} 25^{\prime}$ east longitude with an elevation of 228 masl. The type of the soil was sandy loam. The area received about $2014.30 \mathrm{~mm}$ of total rainfall during the entire growing season.

The experiment was laid out in strip- split design with twelve treatments and three replications. Treatments consisted of two different tillage methods namely conventional tillage (CT) and zero tillage (ZT) as vertical factor, two different levels of residue (residue kept and residue removed) as horizontal factor and three different levels of cropping systems namely sole maize, sole soybean and maize + soybean intercropping system as sub plot factor. Manakamana-3 and Puja were the variety of maize and soybean used for the experiment respectively.

The individual gross plot size was of $24 \mathrm{~m}^{2}$ having the length of $6 \mathrm{~m}$ and width of $4 \mathrm{~m}$. Row to row spacing for each plot was maintained at $100 \mathrm{~cm}$ so that every plot received 6 rows of maize where two outer rows were marked as boarder rows, next two rows were for destructive sampling and two inner rows were net plot. The number of rows of maize was fixed as six in each treatment and plant to plant spacing was of $50 \mathrm{~cm}$ and 2 plants per hill were maintained. On the other hand, the number of rows per plot of soybean was varied depending upon the row ratio of soybean and sole planting. It was 10 rows for $1: 2$ and 12 rows for sole planting. The spacing for both 1:2 ratio and sole planting was $50 \times 10 \mathrm{~cm}^{2}$ fixed in all treatments. The net plot of maize consisted of 2 central rows $\left(8 \mathrm{~m}^{2}\right)$ and in case of soybean it was 4 rows in both 1:2 ratio and sole crop. However, the net harvesting area of soybean in all treatments was the same $\left(8 \mathrm{~m}^{2}\right)$.

\section{Results and Discussion}

\subsection{Phenological Observation of Maize Days to $\mathbf{9 0 \%}$ Germination}

Days to $90 \%$ germination of maize did not vary significantly due to tillage, residue levels and intercropping systems (Table 1). However, crop took longer period of 5.75 days to $90 \%$ germination in CT as compared ZT with 4.92 days.

\subsection{Days to $\mathbf{9 0 \%}$ Tasseling}

The first signal of the initiation of reproductive growth of maize is tasseling and silking. Once tasseling dates are known, we can have a better speculation for the maturity period of the crop.

Analysis of variance for days to $90 \%$ tasseling in tillage, residue levels and intercropping systems treatments registered non-significant differences (Table 1). On an average, the tesseling in maize occurred at 58.17 DAS.

\subsection{Days to $90 \%$ Silking}

The analysis of variance for days to $90 \%$ silking of maize in tillage, residue levels and different intercropping systems treatments revealed non-significant differences (Table 1). On an average, the silking in maize occurred at 61.71 DAS.

Table 1. Effect of tillage, residue levels and intercropping system on phenology of maize at Rampur, Chitwan, Nepal, 2013

\begin{tabular}{|c|c|c|c|c|}
\hline \multirow{4}{*}{ Treatments } & \multicolumn{4}{|c|}{ Phenological stages } \\
\hline & \multicolumn{4}{|c|}{ DAS } \\
\hline & $90 \%$ & $90 \%$ & $90 \%$ & $90 \%$ \\
\hline & Germination & Tasseling & Silking & Maturity \\
\hline \multicolumn{5}{|c|}{ Tillage } \\
\hline Conventional & 5.75 & 57.75 & 61.25 & 95.25 \\
\hline Zero & 4.92 & 58.58 & 62.17 & 94.00 \\
\hline $\mathrm{SEm} \pm$ & 0.26 & 0.62 & 0.46 & 0.45 \\
\hline LSD & Ns & Ns & Ns & Ns \\
\hline \multicolumn{5}{|c|}{ Residue levels } \\
\hline $\begin{array}{l}\text { Residue } \\
\text { removed }\end{array}$ & 5.42 & 58.00 & 61.83 & 95.67 \\
\hline Residue kept & 5.25 & 58.33 & 61.58 & 94.58 \\
\hline $\mathrm{SEm} \pm$ & 0.06 & 0.16 & 0.37 & 0.10 \\
\hline LSD & Ns & Ns & Ns & Ns \\
\hline \multicolumn{5}{|c|}{ Intercropping systems } \\
\hline Sole maize & 5.34 & 58.50 & 61.75 & $95.25^{\mathrm{a}}$ \\
\hline $\begin{array}{l}\text { Maize+ } \\
\text { soybean }\end{array}$ & 5.33 & 57.83 & 61.67 & $94.00^{\mathrm{b}}$ \\
\hline $\mathrm{SEm} \pm$ & 0.14 & 0.45 & 0.32 & 0.92 \\
\hline LSD & Ns & Ns & Ns & 0.81 \\
\hline $\mathrm{CV} \%$ & 9.38 & 2.70 & 1.81 & 1.01 \\
\hline Grand mean & 5.33 & 58.17 & 61.71 & 94.63 \\
\hline
\end{tabular}

\subsection{Physiological Maturity}

The days to physiological maturity (PM) was not significantly influenced by tillage and residue (Table 1 ). These results for the tillage effect are in line with the findings of Tangadulratana (1985), who reported that 
different tillage practices did not delay physiological maturity in maize.

Grand mean of physiological maturity of maize was 94.63 DAS. The effect of intercropping systems was found significant on physiological maturity (Table 1). PM period was found significantly longer in sole maize system (95.25) as compared to maize and soybean intercropping system (94). The reduction in number of days to physiological maturity in intercropping system might be attributed to the competition effect for nutrient, space and moisture and which in deficit condition can result in lowered metabolic processes in the plant.

\subsection{Biometric Observations of Maize Plant Height (cm)}

Tillage and residue management did not affect significantly on plant height at all dates of observations but the intercropping systems influenced significantly (Table 2). The average height of maize at 30, 45, 60 and 75 DAS was $128.78 \mathrm{~cm}, 235.73 \mathrm{~cm}, 245.39 \mathrm{~cm}$ and $245.25 \mathrm{~cm}$, respectively.

Effect of intercropping systems on plant height of maize was significant at all dates of observation except 30 DAS (Table 2). Height of maize was significantly higher at 45, 60 and 75 DAS in sole maize plots whereas in maize and soybean intercropping plots, significantly lower height of maize was recorded. Higher plant height in sole cropped maize might be due to better utilization of solar radiation and $\mathrm{CO}_{2}$ as there was no competition with intercrop resulting in better $\mathrm{N}$ uptake and less weed infestation.

Table 2. Plant height of maize as influenced by tillage, residue levels and intercropping system at Rampur, Chitwan, Nepal, 2013

\begin{tabular}{|c|c|c|c|c|}
\hline \multirow{3}{*}{ Treatments } & \multicolumn{4}{|c|}{ Plant height $(\mathrm{cm})$} \\
\hline & \multicolumn{4}{|c|}{ DAS } \\
\hline & 30 & 45 & 60 & 75 \\
\hline \multicolumn{5}{|c|}{ Tillage } \\
\hline Conventional & 130.08 & 236.69 & 248.33 & 248.17 \\
\hline Zero & 127.48 & 234.77 & 242.45 & 242.33 \\
\hline SEm \pm & 1.16 & 2.11 & 2.79 & 2.80 \\
\hline LSD & Ns & Ns & Ns & Ns \\
\hline \multicolumn{5}{|l|}{ Residue levels } \\
\hline Residue removed & 129.31 & 236.63 & 244.23 & 244.08 \\
\hline Residue kept & 128.25 & 234.83 & 246.55 & 246.42 \\
\hline SEm \pm & 0.29 & 2.99 & 3.45 & 3.39 \\
\hline LSD & Ns & Ns & Ns & Ns \\
\hline \multicolumn{5}{|c|}{ Intercropping systems } \\
\hline Sole maize & 130.71 & $238.39^{\mathrm{a}}$ & $248.56^{\mathrm{a}}$ & $248.50^{\mathrm{a}}$ \\
\hline Maize + soybean & 126.85 & $233.06^{b}$ & $242.22^{\mathrm{b}}$ & $242.00^{\mathrm{b}}$ \\
\hline SEm \pm & 1.63 & 1.44 & 1.91 & 1.95 \\
\hline LSD & Ns & 4.68 & 6.24 & 6.36 \\
\hline $\mathrm{CV} \%$ & 4.37 & 2.11 & 2.7 & 2.76 \\
\hline Grand mean & 128.78 & 235.73 & 245.39 & 245.25 \\
\hline
\end{tabular}

Days after sowing (DAS), Non-significant (Ns). Means followed by the common letter within each column are not significantly different at 5\% level of significance by DMRT

\subsection{Number of Leaves per Plant}

The average number of leaves per plant was increasing from 30 DAS to silking 60 DAS and then after declined at cob development stage (75 DAS) due to shedding and drying of old leaves. There was no significant effect of tillage, residue levels and intercropping systems on the number of leaves per plant across all the time series (Table $3)$.
Table 3. Effect of tillage, residue levels and intercropping system on number of leaves plant ${ }^{-1}$ of maize at Rampur, Chitwan, Nepal, 2013

\begin{tabular}{|c|c|c|c|c|}
\hline \multirow{3}{*}{ Treatments } & \multicolumn{4}{|c|}{ Number of leaves plant $^{-1}$} \\
\hline & \multicolumn{4}{|c|}{ DAS } \\
\hline & 30 & 45 & 60 & 75 \\
\hline \multicolumn{5}{|c|}{ Tillage } \\
\hline Conventional & 6.82 & 11.27 & 15.72 & 15.25 \\
\hline Zero & 5.46 & 10.35 & 15.77 & 15.25 \\
\hline SEm \pm & 0.43 & 0.17 & 0.69 & 0.64 \\
\hline LSD & Ns & Ns & Ns & Ns \\
\hline \multicolumn{5}{|c|}{ Residue levels } \\
\hline Residue removed & 6.29 & 11.00 & 15.17 & 14.67 \\
\hline Residue kept & 5.98 & 10.62 & 16.32 & 15.83 \\
\hline SEm \pm & 0.43 & 0.5 & 0.24 & 0.21 \\
\hline LSD & Ns & Ns & Ns & Ns \\
\hline \multicolumn{5}{|c|}{ Intercropping systems } \\
\hline Sole maize & 6.04 & 11.04 & 15.85 & 15.33 \\
\hline Maize + soybean & 6.23 & 10.57 & 15.64 & 15.17 \\
\hline SEm \pm & 0.26 & 0.55 & 0.17 & 0.16 \\
\hline LSD & Ns & Ns & Ns & Ns \\
\hline $\mathrm{CV} \%$ & 14.51 & 17.59 & 3.68 & 3.54 \\
\hline Grand mean & 6.14 & 10.81 & 15.75 & 15.25 \\
\hline
\end{tabular}

Days after sowings (DAS), Non-significant (Ns). Means followed by the common letter within each column are not significantly different at 5\% level of significance by DMRT

\subsection{Leaf Area Index}

Leaf area index (LAI) of maize varied significantly with intercropping systems but LAI did not vary significantly in response to tillage and residue at all dates of observations (Table 4). However, higher LAI was observed in CT than ZT across the time series. Significantly, higher LAI was measured at all dates of observations under sole maize except at 30 DAS. LAI was increased from knee high stage (30 DAS) up to silking stage (60 DAS) and it decreased from silking stage to cob development stage (75 DAS).

Table 4. Effect of tillage, residue levels and intercropping systems on leaf area index of maize at Rampur, Chitwan, Nepal, 2013

\begin{tabular}{|c|c|c|c|c|}
\hline \multirow{3}{*}{ Treatments } & \multicolumn{4}{|c|}{ Leaf area index (LAI) } \\
\hline & \multicolumn{4}{|c|}{ DAS } \\
\hline & 30 & 45 & 60 & 75 \\
\hline \multicolumn{5}{|c|}{ Tillage } \\
\hline Conventional & 0.67 & 2.3 & 3.4 & 2.44 \\
\hline Zero & 0.63 & 2.27 & 3.37 & 2.38 \\
\hline SEm \pm & 0.03 & 0.04 & 0.02 & 0.05 \\
\hline LSD & Ns & Ns & Ns & Ns \\
\hline \multicolumn{5}{|c|}{ Residue levels } \\
\hline Residue removed & 0.61 & 2.31 & 3.48 & 2.38 \\
\hline Residue kept & 0.69 & 2.26 & 3.3 & 2.44 \\
\hline LSD & Ns & Ns & Ns & Ns \\
\hline SEm \pm & 0.03 & 0.14 & 0.04 & 0.08 \\
\hline \multicolumn{5}{|c|}{ Intercropping systems } \\
\hline Sole maize & 0.68 & $2.56^{\mathrm{a}}$ & $3.57^{\mathrm{a}}$ & $2.66^{\mathrm{a}}$ \\
\hline Maize + soybean & 0.62 & $2.01^{\mathrm{b}}$ & $3.20^{\mathrm{b}}$ & $2.18^{\mathrm{b}}$ \\
\hline SEm \pm & 0.05 & 0.14 & 0.1 & 0.13 \\
\hline LSD & Ns & 0.47 & 0.34 & 0.42 \\
\hline $\mathrm{CV} \%$ & 24.44 & 22.01 & 10.6 & 18.4 \\
\hline Grand mean & 0.65 & 2.29 & 3.39 & 2.41 \\
\hline
\end{tabular}

Days after sowings (DAS), Non-significant (Ns). Means followed by the common letter within each column are not significantly different at 5\% level of significance by DMRT

\subsection{Total Dry Matter Accumulation $\left(\mathrm{g} \mathrm{m}^{-2}\right)$}

Effect of tillage and residue on total dry matter production $\left(\mathrm{g} \mathrm{m}^{-2}\right)$ was not significant. However, the higher total dry matter accumulation was recorded in CT compared to ZT at all stages of crop (Table 5). Slightly higher total dry matter production was measured at the time of harvest in residue kept plots. The CT treatment showed the higher value of corn dry matter probably due 
to the deep root proliferation and less competition by weeds.

Intercropping systems had a significant effect on total dry matter accumulation of maize as shown in Table 5. The effect of intercropping systems at 30 DAS and 45 DAS was not significant but significantly higher total dry matter accumulation was recorded from 60 DAS up to at harvest stage under sole maize compared to maize and soybean intercropping system.

Table 5. Effect of tillage, residue levels and intercropping system on dry matter accumulation of maize at Rampur, Chitwan, Nepal, 2013

\begin{tabular}{|c|c|c|c|c|c|}
\hline \multirow{3}{*}{ Treatments } & \multicolumn{5}{|c|}{ Total dry matter accumulation $\left(\mathrm{g} \mathrm{m}^{-2}\right)$} \\
\hline & \multicolumn{5}{|c|}{ DAS } \\
\hline & 30 & 45 & 60 & 75 & At harvest \\
\hline \multicolumn{6}{|c|}{ Tillage } \\
\hline Conventional & 45.54 & 220.33 & 552.42 & 854.67 & 1146.83 \\
\hline Zero & 43.58 & 218.83 & 549.33 & 853 & 1133.33 \\
\hline SEm \pm & 1.54 & 9.81 & 16.73 & 20.38 & 12.37 \\
\hline LSD & Ns & Ns & Ns & Ns & Ns \\
\hline \multicolumn{6}{|c|}{ Residue levels } \\
\hline Residue removed & 43.9 & 226.33 & 555.25 & 858.5 & 1140.5 \\
\hline Residue kept & 45.22 & 212.33 & 546.5 & 849.18 & 1139.67 \\
\hline SEm \pm & 2.22 & 13.06 & 11.87 & 8.61 & 44.52 \\
\hline LSD & Ns & Ns & Ns & Ns & Ns \\
\hline \multicolumn{6}{|c|}{ Intercropping systems } \\
\hline Sole maize & 44.95 & 225.83 & $583.00^{\mathrm{a}}$ & $875.33^{\mathrm{a}}$ & $1176.33^{\mathrm{a}}$ \\
\hline Maize +Soybean & 44.17 & 213.33 & $518.75^{b}$ & $832.33^{\mathrm{b}}$ & $1103.83^{b}$ \\
\hline SEm \pm & 2.79 & 14.28 & 18.82 & 11.29 & 22.22 \\
\hline LSD & Ns & Ns & 55.06 & 36.83 & 65.02 \\
\hline $\mathrm{CV} \%$ & 21.68 & 22.52 & 11.84 & 5.98 & 6.75 \\
\hline Grand mean & 44.56 & 219.58 & 550.87 & 853.83 & 1140.08 \\
\hline
\end{tabular}

Days after sowings (DAS), Non-significant (Ns). Means followed by the common letter within each column are not significantly different at 5\% level of significance by DMRT

\subsection{Yield Attributing Characters of Maize}

Yield attributing characters like kernels row per cob, kernels per cob, kernels per cob row, cob length and cob diameter were varied significantly due to intercropping systems but it was not affected significantly by tillage methods and residue levels.

\subsection{Number of Plants at Harvest (Thousands ha ${ }^{-1}$ )}

Number of plants at harvest was not affected significantly by tillage system, residue and intercropping systems (Table 6). However, more number of plants was harvested at CT (35.04 thousand ha $^{-1}$ ) compared to ZT (34.79 thousand $\mathrm{ha}^{-1}$ ). The reason for lower corn population in ZT was due to the crop weed competition during the initial growth stage.

Likewise, total number of plants at harvest was higher in Residue removed plot (35.22 thousands $\mathrm{ha}^{-1}$ ) and sole maize system (35.04 thousands $\mathrm{ha}^{-1}$ ) compared with residue retention plots (34.61 thousands $\mathrm{ha}^{-1}$ ) and maize soybean intercropping system respectively.

\subsection{Number of Kernel Rows Per Cob}

Number of rows per cob was not affected significantly by the tillage methods and residue but intercropping systems had significant effect on number of kernel rows per cob in case of maize (Table 6). Number of kernel rows per cob was found significantly higher in sole maize system (12.73) whereas under maize and soybean intercropping system it was found significantly lower (12.26).

\subsection{Number of Kernels per Row}

The grand mean number of kernel per row was found to be 30.50. Number of kernels per row was not significantly affected by tillage system and residue levels while intercropping systems influenced the number of kernel per row significantly (Table 6). Significantly higher number of kernels per row was recorded under sole maize system (31.27) compared with maize and soybean intercropping system (29.73).

\subsection{Number of Kernels per Cob}

Intercropping systems affected significantly the number of kernels per cob of maize (Table 6). Higher number of kernels per cob (384.94) was observed with sole maize system as compared to maize and soybean intercropping system (359.87), while tillage methods and residue levels showed statistically insignificant variation.

Table 6. Effect of tillage, residue and intercropping system on yield attributing characters of maize at Rampur, Chitwan, Nepal, 2013

\begin{tabular}{|c|c|c|c|c|}
\hline Treatments & $\begin{array}{l}\text { No. of plants at } \\
\text { harvest '000 ha' }\end{array}$ & $\begin{array}{l}\text { Kernel } \\
\text { per } \\
\text { row }\end{array}$ & $\begin{array}{l}\text { Kernel } \\
\text { row per } \\
\text { cob }\end{array}$ & $\begin{array}{l}\text { Kernel } \\
\text { per cob }\end{array}$ \\
\hline \multicolumn{5}{|l|}{ Tillage } \\
\hline Conventional & 35.04 & 30.63 & 12.54 & 378.6 \\
\hline Zero & 34.79 & 30.36 & 12.45 & 366.21 \\
\hline SEm \pm & 0.36 & 0.48 & 0.1 & 6.32 \\
\hline LSD & Ns & Ns & Ns & Ns \\
\hline \multicolumn{5}{|l|}{ Residue levels } \\
\hline $\begin{array}{l}\text { Residue } \\
\text { removed }\end{array}$ & 35.22 & 30.83 & 12.52 & 375.01 \\
\hline Residue kept & 34.61 & 30.17 & 12.46 & 369.8 \\
\hline SEm \pm & 0.41 & 0.22 & 0.04 & 4.63 \\
\hline LSD & Ns & Ns & Ns & Ns \\
\hline \multicolumn{5}{|l|}{$\begin{array}{l}\text { Intercropping } \\
\text { systems }\end{array}$} \\
\hline Sole maize & 35.04 & $31.27^{\mathrm{a}}$ & $12.73^{\mathrm{a}}$ & $384.94^{\mathrm{a}}$ \\
\hline Maize+ Soybean & 34.8 & $29.73^{b}$ & $12.26^{\mathrm{b}}$ & $359.87^{b}$ \\
\hline SEm \pm & 0.52 & 0.37 & 0.14 & 7.64 \\
\hline LSD & Ns & 1.2 & 0.45 & 24.91 \\
\hline $\mathrm{CV} \%$ & 5.12 & 4.19 & 3.81 & 7.11 \\
\hline Grand mean & 34.92 & 30.5 & 12.5 & 372.41 \\
\hline
\end{tabular}

Initial plant population 40.00 thousands maize plants ha $^{-1}$. Non-

significant (Ns). Means followed by the common letter within each column are not significantly different at $5 \%$ level of significance by DMRT

\subsection{0-grain Weight (g)}

Thousands grain weight is one of the most important yield attributing parameter of maize. In this experiment, all the tested factors i.e. tillage, residue levels and intercropping systems found to have no significant effect on thousand-grain weight (Table 7). Thole (2007) also found similar results and reported that intercropping system had no significant effect on 1000-grain weight of maize.

\subsection{Shelling Percentage}

Shelling percentage of maize was significantly affected by intercropping system (Table 7). Under sole maize system, significantly higher shelling percentage (76.33) was recorded whereas significantly lower shelling percentage (74.46) was recorded in maize and soybean 
intercropping system while the effect of tillage and residue on shelling percentage of maize was not obvious.

\subsection{Length of Cob (cm)}

Intercropping systems had significant effect on length of cob in maize (Table 7). Sole maize system produced significantly higher length of cob in maize $(14.40 \mathrm{~cm})$ as compared with maize and soybean intercropping system $(13.28 \mathrm{~cm})$ whereas tillage and residue displayed nonsignificant difference on length of cob.

\subsection{Diameter of Cob (cm)}

Similarly, intercropping system had a significant effect on diameter of cob (Table 7). Significantly, higher diameter of cob $(4.45 \mathrm{~cm})$ was obtained in sole maize system, whereas significantly lower diameter of cob (4.22 $\mathrm{cm}$ ) was recorded under maize and soybean intercropping system but effect of tillage and residue on diameter of cob was found non-significant.

Table 7. Effect of tillage, residue and intercropping system on yield attributing characters of maize at Rampur, Chitwan, Nepal, 2013

\begin{tabular}{|c|c|c|c|c|}
\hline \multirow[b]{2}{*}{ Treatments } & \multicolumn{4}{|c|}{ Yield attributing characters } \\
\hline & $\begin{array}{l}1000 \text { grain } \\
\text { weight }(\mathrm{g})\end{array}$ & Shelling\% & $\begin{array}{l}\text { Length of } \\
\text { cob }(\mathrm{cm})\end{array}$ & $\begin{array}{c}\text { Diameter of } \\
\text { cob }(\mathrm{cm})\end{array}$ \\
\hline \multicolumn{5}{|l|}{ Tillage } \\
\hline Conventional & 298.5 & 75.75 & 14.09 & 4.3 \\
\hline Zero & 300.83 & 75.05 & 13.58 & 4.36 \\
\hline SEm \pm & 7.001 & 0.36 & 0.27 & 0.07 \\
\hline LSD & Ns & Ns & Ns & Ns \\
\hline \multicolumn{5}{|c|}{ Residue levels } \\
\hline $\begin{array}{l}\text { Residue } \\
\text { removed }\end{array}$ & 300.67 & 75.68 & 14.08 & 4.39 \\
\hline Residue kept & 298.67 & 75.12 & 13.59 & 4.28 \\
\hline $\mathrm{SEm} \pm$ & 7.06 & 1.03 & 0.32 & 0.04 \\
\hline LSD & NS & NS & NS & NS \\
\hline \multicolumn{5}{|c|}{ Intercropping systems } \\
\hline Sole maize & 299.5 & $76.33^{\mathrm{a}}$ & $14.40^{\mathrm{a}}$ & $4.45^{\mathrm{a}}$ \\
\hline $\begin{array}{l}\text { Maize } \\
\text { +soybean }\end{array}$ & 299.83 & $74.46^{\mathrm{b}}$ & $13.28^{\mathrm{b}}$ & $4.22^{\mathrm{b}}$ \\
\hline SEm \pm & 7.16 & 0.4 & 0.3 & 0.07 \\
\hline LSD & Ns & 1.3 & 0.97 & 0.21 \\
\hline $\mathrm{CV} \%$ & 8.29 & 1.83 & 7.48 & 5.19 \\
\hline Grand mean & 299.66 & 75.39 & 13.84 & 4.25 \\
\hline
\end{tabular}

\subsection{Grain and Stover Yield ( $\left(\mathrm{ha}^{-1}\right)$}

Tillage system had no significant effect on grain yield of maize (Table 8). However, grain yield of maize was found higher in CT (4.53 $\left.\mathrm{t} \mathrm{ha}^{-1}\right)$ as compared to ZT (4.49 t $\mathrm{ha}^{-1}$ ). Non-significant difference in yield of maize is due to non-significant difference in biometric traits like leaf area index, total dry matter accumulation and yield attributing characters such as 1000-grain weight, length of cob, diameter of cob etc. Likewise, grain yield of maize was not significantly influenced by residue levels (Table 8). However, higher grain yield was recorded in residue removed plot (4.62 $\mathrm{t} \mathrm{ha}^{-1}$ ) as compared to residue kept plot $\left(4.42 \mathrm{t} \mathrm{ha}^{-1}\right)$. Lower yield in residue kept plot might be due to the lodging of more number of plants caused by termite attack and infection on cob.

Intercropping system had a significant effect on grain yield of maize (Table 8). Significantly higher grain yield of maize (4.76 $\left.\mathrm{tha}^{-1}\right)$ was obtained in sole maize system as compared to maize and soybean intercropping system
(4.27 $\mathrm{t} \mathrm{ha}^{-1}$ ). Under maize and soybean intercropping system, there was 10 percent reduction of maize yield as compared to sole maize system. Undie et al. (2012) found similar results and reported that sole crop of maize produced significantly higher grain yield than any of the intercrop arrangements.

Tillage system as well as residue and intercropping systems showed non significant difference on stover yield of maize (Table 8). The average mean of stover yield was $6.75 \mathrm{tha}^{-1}$.

\subsection{Harvest Index (HI)}

The partitioning of biomass between vegetative and grain tissue should be affected by tillage, residue and intercropping systems. This partitioning is often expressed as grain dry matter divided by the total harvestable biomass known as harvest index. Harvest index of maize did not vary significantly in response to tillage, residue and intercropping systems (Table 8). The average HI of the experiment was 0.41 .

Table 8. Effect of tillage, residue and intercropping systems on grain yield, stover yield and harvest index of maize at Rampur, Chitwan, Nepal, 2013

\begin{tabular}{cccc}
\hline Treatments & $\begin{array}{c}\text { Grain yield (t } \\
\left.\text { ha }^{-1}\right)\end{array}$ & $\begin{array}{c}\text { Stover yield (t } \\
\left.\text { ha }^{-1}\right)\end{array}$ & $\begin{array}{c}\text { Harvest } \\
\text { index }\end{array}$ \\
\hline Tillage & & & \\
\hline Conventional & 4.53 & 7.28 & 0.39 \\
Zero & 4.49 & 6.21 & 0.42 \\
SEm \pm & 0.08 & 0.32 & 0.01 \\
LSD & Ns & Ns & Ns \\
\hline Residue levels & & & 0.43 \\
\hline Residue removed & 4.62 & 6.46 & 0.39 \\
Residue kept & 4.42 & 7.03 & 0.02 \\
SEm \pm & 0.14 & 0.51 & Ns \\
LSD & Ns & & \\
\hline Intercropping & & & 0.41 \\
system & & 7.11 & 0.40 \\
\hline Sole maize & $4.76^{\mathrm{a}}$ & 6.38 & 0.02 \\
Maize + soybean & $4.27^{\mathrm{b}}$ & 0.47 & $\mathrm{Ns}$ \\
SEm \pm & 0.12 & $\mathrm{Ns}$ & 17.22 \\
LSD & 0.40 & 24.18 & 0.41 \\
CV\% & 9.46 & 6.75 & . \\
\hline Grand mean & 4.52 &
\end{tabular}

Non-significant (Ns). Means followed by the common letter within each column are not significantly different at $5 \%$ level of significance by DMRT

\subsection{Yield Advantage of System}

Since the maize and soybean were involved in intercropping experiment, it is not logical to compare total yield of two crops in one system with other. Thus, some of the indices are used here to evaluate the biological suitability of the intercropping system.

\subsection{Maize Grain Yield Equivalent ( $\mathrm{ha}^{-1}$ )}

The grain yield of the intercrop converted into equivalent grain yield of any crop based on the existing market price of the produce called grain yield equivalent (Reddy and Reddi, 2002).

Maize grain yield equivalent ( $\mathrm{t} \mathrm{ha}^{-1}$ ) was not significantly affected by tillage system and residue levels (Table 9) but the grain equivalent of the maize varied significantly due to the intercropping systems. Significantly, higher maize grain yield equivalent (6.45 t $\mathrm{ha}^{-1}$ ) was obtained in sole soybean system followed by maize soybean intercropping system $\left(4.99 \mathrm{t} \mathrm{ha}^{-1}\right)$. It was 
due to the higher grain yield and higher existing market price of component soybean (Rs. 80 per kg), while the existing market price of maize grain was Rs. 30 per kg. Whereas in sole maize system, significantly lower (3.47 t $\mathrm{ha}^{-1}$ ) grain yield equivalent was recorded.

Thus, in respect of grain equivalent yield, maize + soybean intercropping was found better than sole maize system. It indicated that equivalent yield was strongly affected by the market price and yield of component crop in intercropping system. Similarly, higher maize equivalent yield produced in maize soybean combination illustrated that intercropping was more profitable over sole planting of maize in rainfed condition.

\subsection{Land Equivalent Ratio (LER)}

Land equivalent ratio is the relative land area under sole crops that is required to produce the yield achieved in intercropping (Willey, 1979). The average LER recorded in the experiment was 1.19 and varied from 1.0 to 1.38 . Intercropping system had significant effect on LER (Table 4). Significantly, higher LER was recorded from maize soybean intercropping system (1.38) where as sole maize and sole soybean recorded only 1.0 LER.

The mean total land equivalent ratio was more than 1.0 in intercropping treatment (1.38), indicating that intercropping of maize and soybean was advantageous over sole crops alone. The maize canopy alone could not utilize all incoming radiation during the growing period and remaining solar radiation was captured by the soybean when grown under maize, showing complementarily in use of resources (Prasad and Brook, 2005). Efficient use of land resource, where land shortage inclines the farmers to grow many crops on small piece of land is one of the rationales of intercropping in the traditional farming systems.

Table 9. Effect of tillage, residue levels and intercropping systems on maize grain yield equivalent and land equivalent ratio at Rampur, Chitwan, Nepal, 2013

\begin{tabular}{ccc}
\hline Treatments & $\begin{array}{c}\text { Maize grain yield } \\
\text { equivalent }\left(\mathrm{t} \mathrm{ha}^{-1}\right)\end{array}$ & $\begin{array}{c}\text { Land equivalent ratio } \\
\text { (LER) }\end{array}$ \\
\hline Tillage & & \\
\hline Conventional & 4.97 & 1.14 \\
Zero & 4.96 & 1.12 \\
SEm \pm & 0.23 & 0.01 \\
LSD & $\mathrm{Ns}$ & \\
\hline Residue levels & & 1.13 \\
\hline Residue removed & 5.03 & 1.12 \\
Residue kept & 4.91 & 0.02 \\
SEm \pm & 0.10 & Ns \\
LSD & Ns & \\
\hline Intercropping & & $1.0^{\mathrm{b}}$ \\
systems & & $1.0^{\mathrm{b}}$ \\
\hline Sole Maize & $3.47^{\mathrm{c}}$ & $1.38^{\mathrm{a}}$ \\
Sole Soybean & $6.45^{\mathrm{a}}$ & 0.01 \\
Maize + Soybean & $4.99^{\mathrm{b}}$ & 0.04 \\
SEm \pm & 0.19 & 4.93 \\
LSD & 0.57 & 1.13 \\
CV\% & 13.34 &
\end{tabular}

\subsection{Economic Evaluation}

Economic evaluation is most important part of this experiment. The indices like land equivalent ratio and grain yield equivalent give the biological suitability of the cropping system. At the same time, intercropping system should be economically viable and profitable too. Thus, some of the economic indices are used to evaluate the profitability of intercropping system. The economics of maize and soybean through tillage, residue and intercropping system was worked out (Table 100).

\subsection{Gross Returns}

The mean gross return of the experiment was NRs. 182.14 thousands per hectare (Table 100). The tillage and residue levels did not significantly influence it. But effect of intercropping system on gross return was found significant. Significantly higher gross return was obtained under maize and soybean intercropping system (NRs. 236.23 thousand $\mathrm{ha}^{-1}$ ) followed by sole soybean system (NRs.160.11 thousand $\mathrm{ha}^{-1}$ ) which was found at par with sole maize (NRs. 150.07 thousand ha ${ }^{-1}$ ). The higher gross return under maize and soybean intercropping system was due to higher land use, higher total yield of maize and soybean and higher marketing price of soybean.

\subsection{Net Returns}

Effect of tillage on net return was found to be nonsignificant (Table 10). However, net return was obtained higher in case of zero tillage (NRs. 107.22 thousands ha-1) as compared to conventional tillage (NRs. 100.28 thousands $\mathrm{ha}^{-1}$ ). Higher net return in ZT might be due to the lower cost of production. Similarly, effect of residue on net return was also found to be non-significant. But intercropping systems affected it significantly (Table 10). Maize and soybean intercropping system produced significantly higher net return (NRs. 140.49 thousands ha $^{-1}$ ) followed by sole soybean (NRs. 89.85 thousands ha ${ }^{-1}$ ) which was at par with net return obtained from sole maize (NRs. 80.91 thousands $\mathrm{ha}^{-1}$ ). Greater net return from intercropping treatment is attributed due to the efficient use of inputs, soil and other resources.

Table 10. Effect of tillage, residue and intercropping systems on production cost, gross return, net return and B: C ratio at Rampur, Chitwan, Nepal, 2013

\begin{tabular}{cccc}
\hline Treatments & $\begin{array}{c}\text { Gross returns NRs } \\
\left(\text { ' } 000 \mathrm{ha}^{-1}\right)\end{array}$ & $\begin{array}{c}\text { Net returns NRs } \\
\left(\text { ' } 000 \mathrm{ha}^{-1}\right)\end{array}$ & $\begin{array}{c}\text { B: C } \\
\text { Ratio }\end{array}$ \\
\hline Tillage & & & \\
\hline Conventional & 183.38 & 100.28 & 2.20 \\
Zero & 180.90 & 107.22 & 2.42 \\
SEm \pm & 7.00 & 7.00 & 0.08 \\
LSD & $\mathrm{Ns}$ & $\mathrm{Ns}$ & $\mathrm{Ns}$ \\
\hline Residue levels & & & \\
\hline Residue removed & 179.36 & 104.12 & 2.36 \\
Residue kept & 184.91 & 103.39 & 2.26 \\
SEm \pm & 4.82 & 4.82 & 0.07 \\
LSD & $\mathrm{Ns}$ & $\mathrm{Ns}$ & $\mathrm{Ns}$ \\
\hline Intercropping & & & $2.18^{\mathrm{b}}$ \\
systems & & $80.91^{\mathrm{b}}$ & $2.28^{\mathrm{b}}$ \\
\hline Sole maize & $150.07^{\mathrm{b}}$ & $89.85^{\mathrm{b}}$ & $2.47^{\mathrm{a}}$ \\
Sole soybean & $160.11^{\mathrm{b}}$ & $140.49^{\mathrm{a}}$ & 0.06 \\
Maize + soybean & $236.23^{\mathrm{a}}$ & $4.77^{\mathrm{a}}$ & 0.16 \\
SEm \pm & 4.77 & 13.71 & 8.50 \\
LSD & 13.71 & 15.94 & 2.31 \\
CV\% & 9.08 & 103.75 & \\
\hline Grand mean & 182.14 & & \\
\hline
\end{tabular}

Non-significant (Ns). Means followed by the common letter within each column are not significantly different at $5 \%$ level of significance by DMRT

\subsection{Benefit: Cost (B: C) Ratio}


Tillage and residue had no significant effect on B: C ratio (Table 10). However, higher $\mathrm{B}: \mathrm{C}$ ratio was obtained from zero tillage with 2.42 as compared to 2.20 in conventional tillage methods, which indicates that $\mathrm{ZT}$ is more profitable than $\mathrm{CT}$. Higher B:C ratio from ZT was due to the lower cost of production and higher gross return.

There was a significant influence of intercropping systems on B: C ratio (Table 10). Maize and soybean intercropping system produced significantly higher $\mathrm{B}$ : C ratio of 2.47 followed by sole soybean with 2.28 , and was at par with 2.18 in sole maize system.

\section{Conclusion}

Maize and soybean intercropping system in rainy season could be grown successfully and found superior over sole cropping system of either crop in Chitwan, Nepal.

Significant reduction in cost of cultivation under zero tillage was worked out over conventional tillage and the B: $\mathrm{C}$ ratio was also higher in zero tillage.

There is little or no short-term yield benefits from zero tillage and crop residues, but both the tillage methods and residue levels were found to be non-significant in terms of yield and related parameters.

The experiment need to be further tested for one more season taking into account the overall qualities of soil along with growth and yield parameters of both the component crops in order to have the robust findings and recommendations.

\section{Acknowledgement}

We would like to express our sincere thanks to National Agriculture Research and Development Fund (NARDF) for providing financial support for this research and
Directorate of Research and Publication of the Institute of Agriculture and Animal Sciences, Rampur, Chitwan, Nepal for valuable supports and we owe our profound thanks to National Maize Research Program family, Rampur for providing necessary facilities and logistic supports during research period.

\section{References}

[1] Cassel, D.K.,C.W.Raczkowskiand H.P. Denton. 1995. Tillage effects on corn production and soil physical conditions. American Journal of Soil Science society 59: 1436-1443.

[2] MoAD. 2012. Stastistical information on Nepalese agriculture, Government of Nepal. Ministry of Agriculture and Development, Agribusiness Promotion and Stastistics Division, Singha Durbar, Kathmandu, Nepal.

[3] MoAD. 2013. Stastistical information on Nepalese agriculture, Government of Nepal. Ministry of Agriculture and Development, Agribusiness Promotion and Stastistics Division, Singha Durbar, Kathmandu, Nepal.

[4] Reddy, T. Y. and G. H. Reddi. 2002. Principles of Agronomy (2 ${ }^{\text {nd }}$ ed.). Kalayani Publisher, New Delhi, India. 522p.

[5] Tangadulratana, R. 1985. Effect of tillage system, weed control and fertilizer application methods on growth and yield of maize (Zea mays L.). Kasetsart University, Bangkok. Graduate School, MLKU/TH (Thailand).

[6] Thole, A. 2007. Adaptability of soybean (Glycine max L.) varieties to intercropping under leaf stripped and detasselled maize (Zea mays L.). M.Sc. Thesis in crop science submitted to Faculty of Agriculture, University of Zimbabwe. P 26.

[7] Undie, U. L., D. F. Wah and E. E. Attoe. 2012. Effect of intercropping and crop arrangement on yield and productivity of late season maize/soybean mixtures in the humid environment of south southern Nigeria. Journal of Agricultural Science 4:41-42.

[8] Willey, R. W. 1979. Intercropping: its importance and research needs. Part I. Competition and yield advantages. Field Crops Abstract 32: 1-10 pp.

[9] Wright, G. C., C. J. Smith and I. B. Nelson. 1988. Growth and yield of soybean under wet soil culture and conventional furrow irrigation in South-Eastern Australia. Irrigation Science 9: 127192. 